\title{
ROJAS' OLD BAWD AND SHAKESPEARE'S OLD LADY: CELESTINA AND THE ANGLICAN REFORMATION
}

\author{
Nicholas G. Round \\ University of Sheffield
}

There is an almost fatal attraction for any British Hispanist in the prospect of establishing a link between Rojas and Shakespeare. With deceptive neatness, the two can be made to stand as boundary-marks at the beginning and end of a century of profound cultural change. These placings, though, merely underwrite the clichés of literary nationalism. They tell us little of what Shakespeare does - and, by contrast, rather too much about what he is supposed to represent, in English and in world literature. As for whatever Rojas does, that becomes the merest pretext: a topic through which the greatness of Shakespeare can yet again be pondered. The underlying assumption remains constant whether or not Rojas is being explicitly downgraded, and irrespective of whether the critic making the judgement comes from an English or a Hispanic background. Thus $\mathrm{H}$. Warner Allen describes Calisto and Melibea as 'worthy precursors' of Romeo and Juliet, ${ }^{1}$ while for Margarita Quijano Terán, Shakespeare as playwright, Othello as text, and Iago as character are 'infinitely superior' to Rojas, the Tragicomedia, and Celestina. ${ }^{2}$ Both, however, take it for granted that Shakespeare's way of making literature is the way to do it. As long as we insist on valuing one author in terms

\footnotetext{
${ }^{1}$ Quoted by Jenaro Artiles, "La Celestina y Romeo y Julieta," in Actas del primer congreso internacional sobre La Celestina', ed. M. Criado de Val (Barcelona: Borrás, 1977), p. 325.

2 Margarita Quijano Terán, 'La Celestina' y 'Otelo'. Estudio de literatura dramática comparada, Ediciones de Filosofía y Letras, 15 (México: UNAM, 1957), p. 169.
} 
deriving from the achievements of the other, there is not much to be learned from bringing the two great names into conjunction.

Yet attempts to define their difference can run just as readily into platitude. Juan Pedro Barricelli, for example, classes Iago as an 'essential' character and Celestina as an 'existential' one, only to lapse into the tired and suspect topos of 'Spanish realism'. ${ }^{3}$ This seems a pity, because so much that is authentically original in Rojas does, in fact, relate to that polarity of the 'essential' and the 'existential'. We might clarify the point by rephrasing it in terms at once more nearly contemporary with Rojas himself and more narrowly linguistic in their reference. Celestina is remarkable as a piece of writing which combines realist discourse realist, that is, in the philosophical sense - with nominalist discourse. Whether construed as the author's rhetorical medium or as the characters' particular utterance, its language blends these elements inextricably together. Time and again, universal judgements are asserted, only to be brought under a commentary that is localized, specific, and deeply corrosive. In that sense (and especially in Celestina's own speeches) the nominalist, existential strand very clearly does prevail. Yet the thing which gives the language of Celestina as a whole its power to matter to us - to be credible, dangerous, urgent - is just this fact of its being, in such cases, a mixed language.

That fact must shift the focus of discussion, if only provisionally, back to possible affinities with Shakespeare, much of whose language is itself 'mixed' in just this sense. Other readers, notably María Rosa Lida de Malkiel, have identified a Shakespearian quality in Rojas' way of imagining his characters. ${ }^{4}$ Again, it is not too hard to see what is meant. But we are left, in both instances, with a problem. . It is that of determining whether we come to recognize these qualities primarily through Rojas' making of his text or through our own reading of it. If the latter, we need to bear in mind how far that reading itself is bound to have been shaped in advance by the experience of reading Shakespeare. The likeness may be there only in the sense that we have found ourselves able to put it there.

${ }^{3}$ Juan Pedro Barricelli, "La Celestina y la naturaleza del mal," Cuadernos Americanos 40.2 (1981), p. 75.

'María Rosa Lida de Malkiel, La originalidad artística de 'La Celestina' (Buenos Aires: EUDEBA, 1962, 1970²), pp. 283-88; the reservations expressed by Stephen Gilman, The Spain of Fermando de Rojas: The Intellectual and Social Landscape of 'La Celestina' (Princeton: Princeton UP, 1972), pp. 13-17, are much to the point. 
Some such dilemma, indeed, seems barely separable from our having any knowledge at all regarding literary texts. The process by which that knowledge comes into being can be characterized, partially but still convincingly, as a constant alternation and interaction between makings and readings. Celestina itself offers one very striking example. Because we are able to read all the later Acts, and to do so with reasonable confidence that they are the work of Fernando de Rojas, we also tend to read Act I as though it were his. If Act I were all that we had, we should read it very differently. This is not merely a matter of our seeing its plot as developing towards an unexpectedly serious end; it has to do with the meanings and effects which we are disposed to find in it. And here at last we do seem to arrive at something which Rojas and Shakespeare can be said, with fair objectivity, to have in common. Both, through the distinctive making of their texts, promote practices of reading which would have been altogether less likely to develop had those texts not been made in those specific ways.

Self-evidently, Rojas had no opportunity to take up the new modes of reading promoted by Shakespeare's making of texts: he died far too soon for that. But Shakespeare could - at least in chronological terms - have practised ways of reading made possible, in the first instance, by Rojas' making of Celestina. He might have applied these to his own reading of the Tragicomedia or of any number of other texts. It is worth asking, then, whether he had any actual (as opposed to merely notional) possibilities of doing these things, and whether in fact he did them; whether a reading of Rojas has left any traces in his work, and above all, supposing that he did read Rojas, how he read him. The point of these questions, though, is not that they enable us associate one wellregarded literary figure with another. Rather, their purpose is to clarify the interplay of makings, readings, and historico-cultural experiences (the third element in the literary process) at moments when it seems to have been working to maximum effect.

We may assume - for lack of any positive evidence - that Shakespeare could not have read Celestina in Spanish. It is notionally possible, but not more, that he could have known one or other of the two French versions current in his time. ${ }^{5}$ But if we set aside these and a few

${ }^{5}$ The anonymous first version has been edited by Gerald J. Brault, 'Celestine': A Critical Edition of the First French Translation (1527) of the Spanish Classic 'La Celestina' (Detroit: Wayne State UP, 1963). Likelier to have come to Shakespeare's notice was Jacques de Lavardin's rendering, now edited by Denis L. Drysdall, 'La Celestina' in the French translation of 1578 by Jacques de Lavardin (London: Tamesis, 
other largely speculative scenarios, we are left with four reasonably well-documented channels through which he could have come to a knowledge of Rojas' work. ${ }^{6}$ The first relevant text, already in print by around 1530, was the Interlude of Calisto and Melibea. In this brief adaptation Melibea remains unseduced: she repents in the nick of time, and is reconciled with her father (here called Danio). Despite this truncated story-line, the Interlude is an intelligently adapted and effectively dramatized piece of work. ${ }^{7}$ But it belongs to a very early phase indeed of secular theatre in England: the appropriate Spanish comparisons would be with Torres Naharro, or even with Juan del Encina. It is hard to see such a text as influential for a radically innovatory playwright, at work in the very last years of the century.

The second possibility is hinted at in some remarks on prevailing theatrical tastes made by the Puritan critic Anthony Munday in a polemic against the stage, composed in 1580 . The comedies of his time, he declares, are 'like the tragical Comedie of Calistus; where the bawdresse Scelestina inflamed the maiden Melibeia with her sorceries' (Brault, 310). That, as we have seen, was not the outcome of the Interlude. Moreover, the phrase 'tragical Comedie' seems to echo the main textual tradition of Celestina's title. Perhaps Munday had read the Tragicomedia in French, or even in Spanish. But that would not, of itself, render his allusion as transparent as it needed to be for the public he was addressing. The likeliest inference, then, is that he was referring to some recent adaptation of Celestina for the English stage, now irretrievably lost.

Again lost, but much more directly attested is the third of our possibilities. On 5th October 1598 the printer William Apsley entered in the Stationers' Register 'a book intituled. The tragick Comedye of

1974).

6 The bibliographical background is lucidly set out by Brault, "English Translations of the Celestina in the Sixteenth Century," Hispanic Review 28 (1960): 301-12, and summarized in Guadalupe Martínez Lacalle, 'Celestine' or the Tragick Comedie of Calisto and Melibea. Translated by James Mabbe (London: Tamesis, 1972), pp. 2-6. Artiles, pp. 330-31 is less securely-based, building injudiciously on a Stationers' Register entry of 1591 which probably refers to a projected reprint in Spanish (Brault, "English Translations," pp. 307-08.

7 See Albert J. Geritz, "Calisto and Melibea: A Bibliography," Celestinesca 3.2 (1979): 45-50. Text in J. S. Farmer, ed., Six Anonymous Plays. First Series (c.15101537), Early English Dramatists (London: Early English Drama Society: 1905), pp. 47-87. 
Celestina / wherein are discoursed in most pleasant stile manye Philosophicall sentences and advertisements verye necessarye for Younge gentlemen. Discoveringe the sleights of treacherous servants and the subtile cariages of filthye bawdes' (Brault, 308). About the filiation of this in the Celestina tradition there is scarcely room for doubt: what Apsley had in view was a translation of the Tragicomedia. On the other hand, we simply do not know whether it was actually printed but has since disappeared, or existed at that time but only in manuscript, or never got beyond being a mere project for a translation.

Finally there is James Mabbe's English version. That did not see print until 1631. But at the head of the manuscript text published some years ago by Guadalupe Martínez Lacalle there is a prose dedication to John Strangeways, Esquire; by 1611, Strangeways had been knighted. At the end of the same text there appears a sonnet dedicated by the translator to the 'right worthie Knight' George Trenchard the Younger; the date of Trenchard's knighthood was 1603. Mabbe's Celestina, then, in this state of the text, was already in existence at some time between those two dates. ${ }^{8}$ It could, of course, have been composed before 1603, and the sonnet to Trenchard added later. It is even possible that it could have been Mabbe's version which Apsley intended printing in 1598. Mabbe would have been about twenty-six at the time. And although he spent most of his life in Magdalen College, Oxford (apart from various diplomatic missions to France and Spain), it is perfectly possible too that he knew Shakespeare. In 1623 he was one of the poets from whom the editors of the First Folio sought and obtained a set of commemorative verses. ${ }^{9}$

There is no very obvious way in which these possibilities of contact with the Celestina tradition ought to be correlated with those plays of Shakespeare in which alleged traces of such contact have from time to time been discerned. ${ }^{10}$ Romeo and Juliet offers a theme - the

${ }^{8}$ Martínez Lacalle, pp. 105-09 (dedication to Strangeways), 268 (verses to Trenchard), 34-35 (consequences for dating).

${ }^{9}$ Biographical details in Martínez Lacalle, pp. 7-13 (pp. 13-14 for the First Folio verses); also P. E. Russell, "A Stuart Hispanist: James Mabbe," Bulletin of Hispanic Studies 30 (1953), 75-84 (possible Shakespearian links, 76, 79-80).

${ }^{10}$ On Romeo and Juliet see especially Artiles; also Pedro Juan Duque Díaz de Cerio, "La presencia de España en Romeo y Julieta," Letras de Deusto 9 (1979): 6394; on Othello, Quijano Terán; also Barricelli. Lida de Malkiel, La originalidad (18990), points to other Celestina-like time-schemes in Hamlet, Troilus and Cressida, and 
doomed lovers - and a character - Juliet's nurse - whose interest in this regard is obvious. Yet at the time of its writing, in 1594 or 1595, Shakespeare had at his disposal only the Interlude (if anyone at all remembered the Interlude by then), or still more problematically, the adaptation apparently referred to by Anthony Munday. Othello, of 1603 or 1604, has in Iago a Celestinesque character of its own; like Celestina too, it employs a double time-scheme to dramatize a tale of passion. And by that date, certainly, Shakespeare could have known Mabbe's translation. Curiously, though, the supposed influence bears much the same indirect character in both these instances. In neither case do those elements which are paralleled in Rojas' work begin, by any measure, to exhaust the thematic and dramatic range of the Shakespearian text.

On the other hand, neither Iago nor the Nurse can be said to embody anything like the full range of Celestina's attributes. On the contrary, each of them seems to take up a different selection of these. The Nurse is the indispensable go-between, facilitating a forbidden love; she even seems to display a certain human spontaneity, by contrast with the rigid codes of family honour. Iago has at his command a Celestinalike rhetoric of temptation and moral disorientation, and the self-interest from which he operates merges, like hers, into an almost disinterestedly destructive malice. But Celestina's own pattern of activity subsumes both sets of attributes. She is at one and the same time indispensable and destructive, profoundly human and radically monstrous. In that sense, the character in whom Shakespeare seems to respond most fully to Rojas' example is Falstaff - not a Celestinesque figure at all, though he does frequent a Celestinesque world. ${ }^{11}$ And he makes his first appearance in Henry IV in 1597 or 1598, just when the English Celestina registered by Apsley might have been starting to circulate in manuscript form. As evidence, that timing is far from conclusive, but it is not without interest either.

Two Gentlemen of Verona (this last, surely, too early for any influence to be at all probable).

${ }^{11}$ On Falstaff see Laurence Senelick, "The Bard and the Bawd," Prologue 30.2 (November 1974), 1. Further specific resemblances to Celestina in Shakespeare's plays are adduced by Lida de Malkiel, Two Spanish Masterpieces: The 'Book of Good Love' and the 'Celestina', Studies in Language and Literature, 49 (Urbana: U Illinois P, 1961), p. 96: King John, Twelfth Night, Much Ado About Nothing, and even the very early Love's Labours Lost. Most of these (and the many others touched upon in La originalidad, passim) seem as likely to be cases of analogy as of actual influence. 
A more specific echo has been suggested by Albert Bagby and William Carroll in the case of $A$ Winter's Tale (1611).12 Here Shakespeare represents the young Prince Florizel as being led by the flight of his falcon to the enclosure ('Thy father's ground') where his beloved lives. The motif is too widely diffused for this to prove any textual link with Calisto and the opening of Celestina. Besides, the happy consequences of Florizel's encounter with Perdita are at an opposite pole from what happens after Calisto has met Melibea. Yet the resemblance does arise at one of the likeliest times for personal contact between Shakespeare and James Mabbe. Like Henry VIII, to which we shall return presently, $A$ Winter's Tale belongs to the last group of plays which Shakespeare wrote. Frances Yates has shown how these pieces are linked ideologically with the political hopes which King James I centred on his two older children, Henry and Elizabeth. ${ }^{13}$ Mabbe, for his part, had close ties with members of Prince Henry's entourage, and especially with Sir John Digby. In 1610 Digby chose him for inclusion in his forthcoming embassy to Madrid, for which Magdalen College granted him leave of absence on 31st December. Mabbe did not leave England, however, until April 1611. Almost certainly he spent the early months of that year - the year of $A$ Winter's Tale - in London. ${ }^{14}$

Based in Madrid for the next four years, Mabbe can have played no direct part in the story of Shakespeare's later output. Prince Henry too was to disappear from the picture, dying in November 1612. But the enormous burden of public expectation which he had carried, with all its hopes of revived Elizabethan glory was not immediately dissipated; instead, it was now transferred to his sister Elizabeth and to Frederick, Prince of the Palatinate, whom she married in London in February 1613. The historical drama Henry VIII bears every appearance of being Shakespeare's contribution (in collaboration, probably, with John

12 Albert J. Bagby, Jr and William M. Carroll, "The Falcon as a Symbol of Destiny: De Rojas and Shakespeare," Romanische Forschungen 83 (1971): 306-10; see, for the wider background, Donald McGrady, "The Hunter Loses his Falcon: Notes on a Motif from Cligès to La Celestina and Lope de Vega," Romania 107 (1986): 145-82.

${ }^{13}$ Frances Yates, Shakespeare's Last Plays: A New Approach (London: Routledge, 1975), pp. 17-35.

${ }^{14}$ Martínez Lacalle, p. 9; Russell, 77. I accept here the dating (a little later than some others) proposed for A Winter's Tale by Yates, p. 10. 
Fletcher) to the public festivities surrounding that marriage. ${ }^{15}$ It deals with events which were crucial for the future greatness of the Tudors and the eventual triumph of Protestantism in England. The name of King Henry, who is shown as growing in prudence and authority throughout the play, also recalled the recently lamented prince. The prophetic speech with which the drama ends promises glory for another Princess Elizabeth and for her successors. The culminating point in a whole array of patriotic spectacle and ceremony is the coronation of Anne Boleyn itself closely and causally linked with another royal marriage. The date of the piece in early 1613 seems confirmed by the description of it as a 'new play' in an eye-witness account of its most celebrated performance. ${ }^{16}$ This was the occasion in late June 1613 when the careless discharge of one of the artillery pieces used in the ceremonial scenes led to a fire in the thatch and the destruction of the entire Globe Theatre. The possibly excessive realism of these elements of spectacle underlined by the alternative title All is True - also appears to connect with a propagandist purpose.

Being in this sense an occasional piece, late in date and with some doubt attaching to its authorship, Henry VIII has, unsurprisingly, received less critical comment than most of Shakespeare's other output. No doubt for that reason, attention does not hitherto seem to have been drawn to the presence in its cast-list of one of Shakespeare's most obviously Celestinesque figures. The cast is a large one, of almost forty named parts. Of these, twenty-five have proper names, deriving from the dramatist's historical sources. Twelve bear the titles of their public or domestic offices: Garter King-at-Arms, a Porter, and so forth. Three anonymous 'Gentlemen', acting as the mouthpieces of wider public opinion, comment from time to time on the developing plot. There remain two named characters who are wholly of the author's own invention: the confidantes, respectively, of Queen Katherine and of Anne Boleyn. To Katherine's friend and counsellor Shakespeare gives an

${ }^{15}$ R. A. Foakes, ed., King Henry VIII, The Arden Edition of the Works of Shakespeare (London: Methuen, 1957), xxviii-xxxiii; also John Margeson, ed., King Henry VIII, The New Cambridge Shakespeare (Cambridge: UP, 1990), pp. 3-4; Yates, p. 67.

${ }^{16}$ Letter of Sir Henry Wotton, 2nd July 1613 (text in Foakes, p. 180, with other contemporary reports). The date of the interrupted performance was 29 th June. 
allegorical name: Patience. Anne's confidante is described simply as 'An Old Lady'. ${ }^{17}$

The two scenes in which the Old Lady appears (II, iii and V, i) present no problems of authorship: they are universally accepted as being by Shakespeare and not by any collaborator. ${ }^{18}$ In the earlier scene, Anne and the Old Lady discuss the troubles of the Queen, an innocent victim of her husband's estrangement. Anne raises the topic of contented poverty; the Old Lady concurs. But when Anne protests that 'By my troth and maidenhead, / I would not be a queen', the reply is swift and contemptuous: 'Beshrew me, I would,/ ... and so would you'. And with an unstoppable flood of sexual double entendre, the Old Lady urges on her mistress the many advantages of worldly greatness. They are interrupted by the Lord Chamberlain, who wants to know what they were talking about. 'Our mistress' sorrows we were pitying', Anne replies - an answer which greatly impresses her visitor. 'It was a gentle business, and becoming/ The action of good women', he observes complacently, and goes on to announce that the King has just made Anne the Marchioness of Pembroke, with a thousand pounds a year. The Old Lady celebrates the news with more jibes against the modesty of Anne's ambitions; the latter does not waver in her views, but does ask her companion to keep the matter of their conversation secret. 'What do you think me?' answers the Old Lady as the scene ends.

In Act V, King Henry is anxiously waiting for news of his new wife's childbed. He has just had an interview with the earnest and virtuous Archbishop Cranmer, to whom he has promised support against the intrigues of his enemies. At this point the Old Lady rushes in, thrusting the royal guards aside. 'Is the Queen deliver'd?' demands the King, 'Say ay, and of a boy.' The Old Lady hedges her reply:

17 Foakes, p. 2; also p. 68 (the list of Dramatis Personae is an editorial extrapolation from earlier texts). All quotations from the play here are taken from this edition.

${ }^{18}$ Texts in Foakes, pp. 68-75, 153-54; on authorship see ibid, pp. xviii-xxvi; also Margeson, pp. 4-14. Both editors see Fletcher's contribution to the play as more limited than has traditionally been claimed. In the present context, it seems worth noting that Shakespeare and Fletcher also appear to have collaborated at about the same date on the lost play Cardenio, whose title suggests a Spanish theme (see MacD. P. Jackson, "The Transmission of Shakespeare's Text," in The Cambridge Companion to Shakespeare Studies, ed. Stanley Wells (Cambridge: UP, 1986), p. 165. 
...Ay, ay, my liege,

And of a lovely boy: the God of heaven

Both now and ever bless her: 'tis a girl

Promises boys hereafter.

Henry hurries off to visit his wife and the new arrival ('as like you / As cherry is to cherry'), ordering his servant, as he goes, to give the Old Lady a hundred marks. She is not impressed: it is payment fit only for a groom. 'Said I for this the girl was like to him?' she grumbles, 'I'll have more, or else unsay ' $t$ '. And off she goes to stake her claim.

The possible echoes of Celestina in all this are obvious enough. One is bound to wonder in the first place why Anne Boleyn's companion had to be an old lady rather than a young one. Besides, her interventions bear a strikingly Celestina-like character: the deceptive acquiescence in ethical commonplace; the strong incitement to a sexual liaison that will bring worldly advancement with it; the role of a messenger who shamelessly manipulates the content of her message. At certain key moments she helps to facilitate the action; yet her mode of expression bids fair to dissolve any notion of stable values in a way that can issue only in chaos. That implicit threat, it is true, remains implicit, and at the level of verbal expression only: the known course of historical events would scarcely have allowed for anything else. But only a very specific imaginative vision of those events would have determined that Anne Boleyn's hopes of greatness should be presented first in a language awash with crude sexual suggestion, or that the birth of the future Queen Elizabeth should be announced in such equivocal terms as these. It is a vision which we might well wish to describe as Celestinesque.

It is, of course, true that the elaboration of secondary meanings of a sexual kind was a wholly characteristic feature of Shakespeare's own use of language. It was this which so disgusted Bernard Shaw in the exchanges between Beatrice and Benedick; it is much to the fore in Mercutio, and in a host of other instances. There is nothing unique even in the density with which these allusions are heaped one upon another: the 'soft cheveril conscience' - at once conscience and pudendum, open and accommodating as a kidskin glove; the 'threepence bow'd' - bent coin or cut-price bawd; 'queen' in its dual sense of sovereign or harlot; 'pluck off', meaning either 'curb your speculations' or 'get undressed'; the 'young count', the 'emballing', the 'burthen' for the back that represents sexual coupling. ${ }^{19}$ None of this requires to be explained by

${ }^{19}$ King Henry VIII, II, iii, 11. 32-47 passim (Foakes, pp. 71-72). 
Rojas' influence or anyone else's. What does tend to support the notion of a debt to Celestina is the deployment of such matter within the dialogue, and the relational pattern which this reveals. Like Melibea (or like Pármeno), Anne Boleyn has just asserted an ethical position which appears to be correct, seriously held, and secure. The Old Lady replies, with an irresistible verbal force, 'No: this and this and this is what you really feel; this - you cannot deny it - is what you are.' Though the contexts and the content are different, that is what Celestina does too. In her other scene again, the Old Lady says nothing especially close to what Celestina says; but she does with the truth what Celestina does with it all the time, reshaping it with the sole aim of her own advantage.

If that is how Rojas' influence works here, one would not expect it to be particularly evident in direct quotation or imitation. Even so, there are in these Shakespearean passages a number of apparent verbal traces of Mabbe's or Rojas' language. The turning-point of the first dialogue:

ANNE: I would not be a queen.

OLD LADY: Beshrew me, I would,-

echoes Celestina's response to Pármeno in Act I:

PÁRMENO: No querría bienes mal ganados. CELESTINA: Yo sí...

which Mabbe, like Shakespeare, amplifies with a mild oath: 'Marrie, Sir, but so would I.' ${ }^{20}$ The Old Lady stresses the value of 'eminence, wealth, sovereignty' as 'blessings' (II, iii, 1. 29), rather as Sempronio insists that if the gifts of Fortune are lacking 'a ninguno acaece en esta vida ser bienaventurado'(p. 38) - though Mabbe, at this point, prefers the more neutral 'happy' to 'blessed'. ${ }^{21}$ The persuasion of Anne Boleyn, like that of Melibea by Celestina in Act IV, has as its point of departure the topic of contentment in poverty; the key element, repeated in Mabbe

${ }^{20}$ Martínez Lacalle, p. 145; cf. King Henry VIII, II, iii, 1. 24, and Rojas' text in Celestina, with the Translation of James Mabbe (1631), ed. Dorothy Sherman Severin (Warminster: Aris \& Phillips, 1987), p. 70. This is the edition used here for all quotations from Rojas, and from the 1631 text of Mabbe; quotations from the Mabbe MS are taken from Martínez Lacalle.

${ }^{21}$ Martinez Lacalle, p. 127 (but of. five lines earlier, "those better sorte of blessinges"). 
-'live contentedly'... 'Trewe contentednes'(p. 170) - perhaps finds an echo in the double occurrence of 'content' in Shakespeare's text (II, iii, 11. $20,22-23) .^{22}$

The more interesting feature here, though, is' the Old Lady's double-edged use of the maxim 'Our content is our best having' (II, iii, 11. 22-23). Looking back towards Anne's previous remarks, this merely reaffirms that true wealth consists in having a quiet mind; looking ahead to the case for ambition which the Old Lady is about to make, it means 'the important thing in life is to get what satisfies us.' There is no equivalent to this in Rojas here, but it is the kind of thing which Celestina does with moral sentences time and again. The ending of this dialogue brings us much closer once more to Celestina and Melibea: the 'innocent' party to the exchanges gives her first clear sign of complicity by begging her temptress to keep their conversation secret. Celestina, like the Old Lady, is indignant at the very suggestion that she might do otherwise: 'Mucho me maravillo, señora Melibea, de la duda que tienes de mi secreto'(p.134) In the manuscript of Mabbe's version this protest is attenuated - 'Doubt not, madam, of my seacresie...' (p. 178) - but the lacuna which follows could well conceal something more complete and emphatic. ${ }^{23}$ As for the Old Lady's second intervention, it may not be irrelevant to recall the words with which Sempronio enquires after the result of that first interview with Melibea: 'Dime si tenemos hijo o hija' (p.142). There is another gap in the manuscript at this point (p. 181), but the 1631 edition has 'Say, is it a son or daughter?' (p. 143).

It seems likely enough, then, that behind the character of the Old Lady there lies a reading (or a re-reading) of Mabbe's Celestina. It could have happened during, or perhaps a little after, those early months of 1611 when Mabbe, preparing in London for his departure with Digby's embassy to Madrid, is likeliest to have been in personal contact with Shakespeare. The latter, it would seem, would have had access to a copy of Celestina differing in some matters of detail from the manuscript version which survives now. But we are clearly not dealing with a case of detailed and deliberate imitation. If he did, in fact, make use of Mabbe in the ways so far indicated, Shakespeare was reworking

22 The verbal (as opposed to thematic) parallels with Rojas' original are not especially close here (cf. Severin, p. 116).

${ }^{23}$ Contrast the 1631 text in Severin, p. 135: "Madame, I much marvel you should entertain any the least doubt of my servie" [sic], and cf. King Henry VIII, II, iii, 1. 107. 
spontaneously various elements, picked up in the course of an attentive reading.

Spontaneous these responses might be, but they must still have obeyed some sort of intention. Their relation to the propagandist drive which so patently underlies other aspects of Henry VIII is, even so, hard to establish in any straightforward fashion. Even on an ideological level there was something radically ambiguous about James I's grand dynastic design. Was he claiming for the House of Stuart the leadership of Protestant Europe? Or did he aspire to make his own monarchy into something more exalted still: the promoter and guarantor of a universal accord among all Christian nations? The political dilemma which this represented was lying in wait for James in the fairly imminent future. For the moment, however, an imaginary re-creation of historical events could evade that awkward choice. ${ }^{24}$ Hence the sympathetic presentation in Henry VIII of such sharply opposed figures as Queen Katherine and Thomas Cranmer. This feature has led critics to characterize the play as 'eclectic', 'tolerant', 'kindly', and 'accommodating'-all of which, in some measure, it is. ${ }^{25}$ Yet it still narrates, with patent approval, key episodes in the origins of the English Reformation; in its final tableau the first Archbishop of that Reformation prophesies a golden age under the Anglican monarchy of Elizabeth and her successors. In order to believe that such a golden age had, in fact, happened it was already necessary to accept a number of largely mythic premises, to which not everyone not the English Recusants; not the Puritans - would readily have given assent. But nobody who knew anything at all about recent history could avoid certain other facts.

To arrive even at the relative tranquillity of the Elizabethan settlement, England had had to pass through episodes of arbitrary violence, bitter discord, and the dissolution of principles of authority which had once been thought eternal. Anne Boleyn had died on the scaffold, condemned for adultery. Cranmer had gone to the stake on the orders of the patient and saintly Katherine's daughter. Henry's serial marriages; the executions for reasons of state - Thomas More, Thomas Cromwell, and so many others; the successive tides of religious persecution - all these things were too well-known to be forgotten. Yet

${ }^{24}$ Henry VIII has been interpreted in both senses (by Frances Yates and by Gwynne Wickham respectively): see Margeson, pp. 27-28.

${ }^{25}$ See Alexander Leggatt, Shakespeare's Political Drama: The History Plays and The Roman Plays (London: Routledge, 1988). 
Shakespeare's mythic presentation of the events from which that history had stemmed invited its audiences to do just that - under the title, moreover, of All is True. The background presence of that Celestinafigure, and her sidelong yet shameless disruption of the play's propagandistic tone, were perhaps ways of recovering truths which Henry VIII had perforce suppressed.

The official tale of events ran like this: King Henry, troubled in his conscience because he had married his deceased brother's wife, had sought a divorce, which the Pope, swayed by temporal interests, declined to grant him; hence the declared independence and subsequent reform of the national Church. The matter of Anne Boleyn was a different, and largely later business. But in another version the king, prevented by the Church from marrying his new mistress, had taken over the Church in order to marry as he chose. The importance which this less official story assigned to Henry's sexual desires undermined the dignity of the public narrative. Yet Shakespeare does seem to have been at some pains to keep this alternative possibility in play. He actually alters the chronology of his main source to put back the date of Henry's first meeting with Anne Boleyn. ${ }^{26}$ He makes much of the celebratory sexual licence in the popular festivities which mark her coronation and her daughter's christening. ${ }^{27}$ It was, of course, an element which could be seen as appropriate in a context of royal births or weddings. But the notion that the reigning monarch's sexual urges had been the primary mover of all these great public events was quite another thing. That notion is what the Celestinesque intervention of the Old Lady contrives to hint at. It was the custom of militant, post-Tridentine Catholicism to attribute the 'schism of England' to the sexual caprice of a tyrant-king, lured by a wanton, ambitious woman. In Henry VIII Anne Boleyn herself maintains a perfect decorum, and scrupulously rejects ambition. But the scabrous language in which the Old Lady urges her on to good fortune

${ }^{26}$ Foakes, p. xxxv; Leggatt, p. 219.

2 This aspect has been seen as a simple reinforcement of Shakespeare's political message - implicitly and approvingly by Margeson, p. 41; explicitly and critically by Leonard Tennenhouse, "Strategies of State and Political Plays: $A$ Midsummer Night's Dream, Henry IV, Henry V, Henry VIII," in Political Shakespeare: New Essays in Cultural Materialism, ed. Jonathan Dollimore and Alan Sinfield (Manchester: UP, 1985), pp. 124-25. 
irresistibly recalls that Irish epigram in which the foundation-stones of the Anglican temple are identified as King Henry's testicles. ${ }^{28}$

Shakespeare, then, appears to have used his Celestinesque character to cast a measure of doubt over what other aspects of his text affirm with perhaps excessive certainty. It happens again on the Old Lady's second appearance. Her threat to deny the resemblance between father and daughter evokes those suspicions of infidelity which were to prove fatal for Anne Boleyn. It hints, too, at that accusation of bastardy which her Catholic enemies at home and abroad had levelled at Queen Elizabeth during her reign. Even the news of the birth, as the Old Lady presents it, exposes the perilous topic of Henry's frustrated dynastic hopes, coolly equating the son he so greatly desires with the daughter who 'Promises boys hereafter' (V, i, l. 166). Elizabeth had not, as it happened, fulfilled that promise. And indeed, the Tudor dynastic and religious crisis, besides breaking the historic relationship of Church and State, had called in question historic norms of legitimate succession, and succession to male heirs. Ideologically these discontinuities had to appear as coherent developments, and that is how the play, especially in its mythic, ceremonial aspect, does present them. But the less harmonious reality also demanded to be shown. The deployment of the Old Lady within the drama seems calculated to do just that. This function, so closely allied with her Celestinesque features, could well have been made possible by Shakespeare's having read Celestina.

If that was what happened, we also have to regard him as a distinctively 'modern' reader of the Tragicomedia, not content to rest upon the purely exemplary interpretation, but alert to those aspects of Celestina's personality and activity which tend to undermine it. It is possible too that his own situation as the son of a recusant father may have some relevance to what he was doing. ${ }^{29}$ We do not have to suppose that this circumstance - by now, several decades in the past would have overruled his attachment to images of English history which

28

Na thracht ar an mhinisteir Ghallda, $\mathrm{Na}$ ar chreidamh gan bheann, gan bhri, Mar ni'l mar bhuan-chloch da theampull, Ach magairle Annraoi, Ri.

Quoted in Brendan Behan, Borstal Boy (London: Corgi Books, 1965; 1st edn, London: Hutchinson, 1958), p. 330.

2 For the evidence - substantial, though not conclusive - of John Shakespeare's recusancy see S. Schoenbaum, "The Life of Shakespeare," Cambridge Companion, p. 2. 
he, through his own work, had done so much to develop. But it could well have given him a residual sense of how arbitrarily founded such images were. The parallel with Fernando de Rojas, the child of a converso-Jewish family, offering exemplary instruction on the basis of a Christian moral order, is hardly one to be dismissed.

Yet this use of the Celestinesque model is still only a very late variant of something whose roots in Shakespeare's historical plays go back much further: the use of feminine interventions to provide access to alternative histories. The language of these interventions, as Phyllis Rackin has shown, is characterized by its difference (it may even, as in the case of Princess Katherine in Henry $V$, be a foreign language), by its frequently heavy load of physical and sexual reference, by a nominalism which opposes grand and overarching historical themes with a counterhistory of private experiences, and by a subversive questioning of patriarchal myths. ${ }^{30}$ It challenges these especially in the matter of patrilineal succession, a crucial topic for every form of legitimism. The secret of who is and who is not his father's son belongs inescapably to the separate world of what women say to one another, and what they alone can know (p. 160). There is a good deal of this in the Old lady's two interventions, from the comic misunderstanding of the Lord Chamberlain - for whom, very clearly, feminine discourse is a world apart - to the final threat that the assumed legitimacy of the newborn heir might come to depend on the liberality of the king.

All this might cast some doubt, not only on Shakespeare's mythic presentation of a national destiny happily achieved, but also on certain assertions made by Rackin herself. She claims, for example, that 'in Henry VIII... women are associated with a benevolent, redemptive providence' (p. 194), and that in this play 'Shakespeare transvalues the feminine and suggests its incorporation into his historical project' (p. 176). Up to a point these things happen; but then the Celestinesque presence threatens to dissolve within its ironies the 'All is True' of any and every historical project, including this one. That, it should perhaps be added, is not at all the same thing as dissolving either history or the

${ }^{30}$ Phyllis Rackin, Stages of History: Shakespeare's English Chronicles (London: Routledge, 1991), Chapter 4 ("Patriarchal History and Female Subversion"), pp. 146-200. 
possibility of historical knowledge. ${ }^{31}$ But it serves as a reminder that between 'All is True' and 'the whole truth' there is a space which only a plurality of experiences and languages can begin to bridge. Shakespeare - and Rojas - knew that very well. ${ }^{32}$

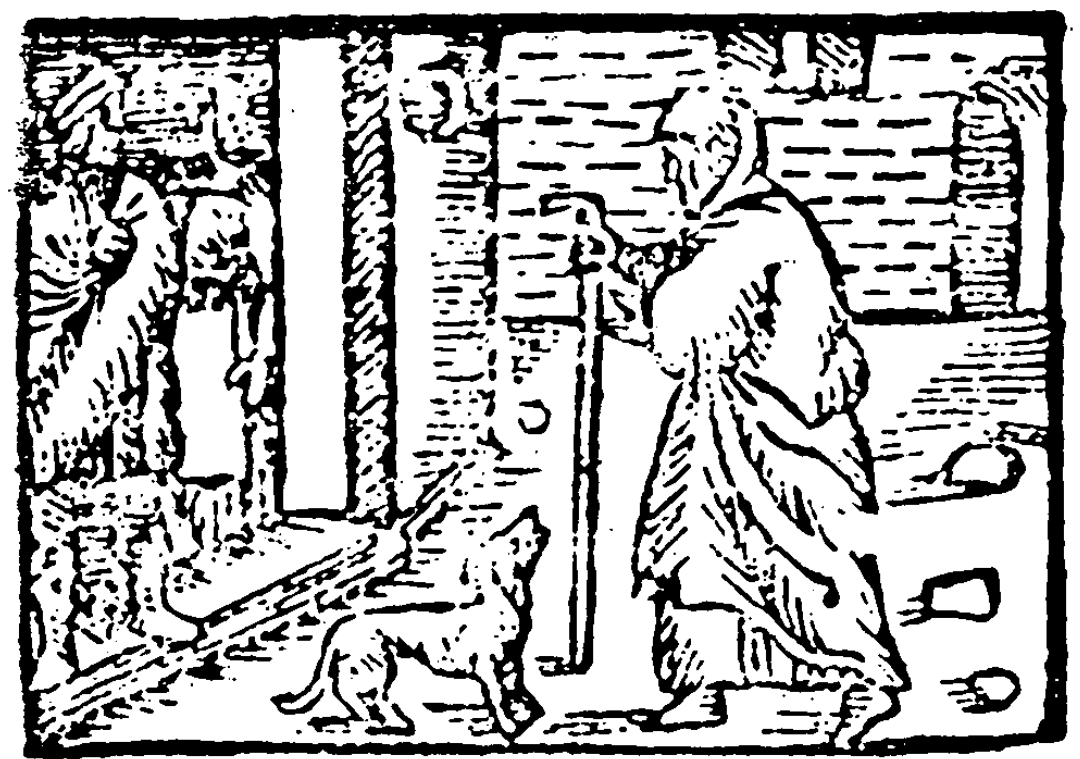

Estella: Adrian de Anvers, 1560.

${ }^{31}$ Rackin herself avoids any such identification - which renders her account all the more convincing. In another context (Nicholas G. Round, "Celestina, Aucto I: A Platonic Echo and its Resonances" in 'Celestina': Approaching the Fifth Centenary, ed. Ivy A. Corfis and Joseph T. Snow (Madison: Hispanic Seminary of Medieval Studies, 1993), p. 107), I offered reasons against seeing Celestina (or Rojas) as "the paladin of... a counter-rational female language." Those reasons, I believe, still obtain. But Phyllis Rackin's book has helped me to see where, in Celestina or in Henry VIII, a possible point of balance might lie.

32 A version of this study was read as a paper to the Conference of the Asociación Internacional de Hispanistas, held in Birmingham in August 1955. I am grateful to Professor Alan Deyermond (then President of the AIH) for permission to publish it here in its revised form. 


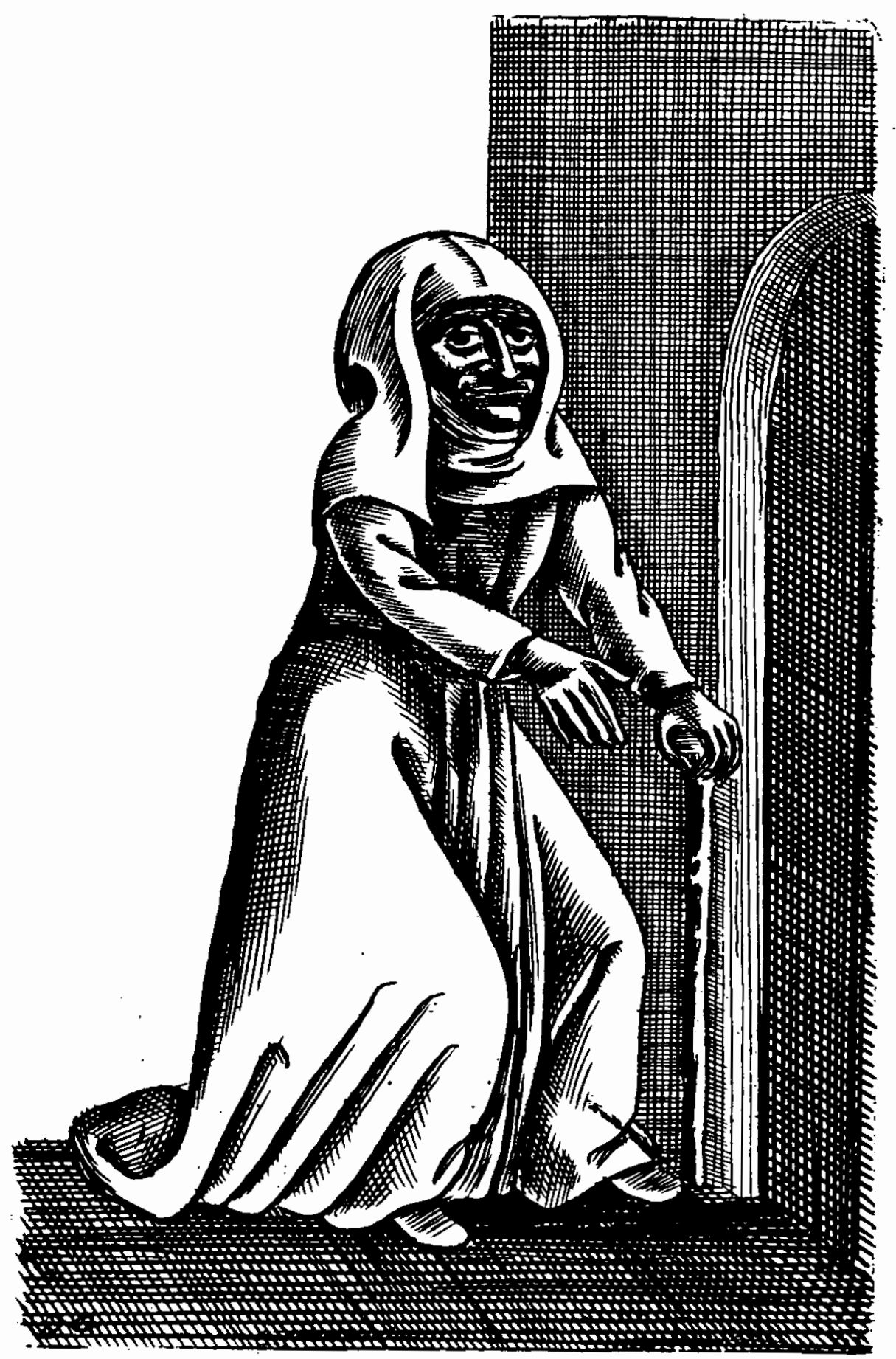

Célestine. Grabado de D. Galanis (1922). 